\title{
COMPARISON OF EDTA AND EDDS ENHANCTED PHYTOEXTRACTION OF Cr AND Pb FROM CONTAMINATED SOIL BY ANANAS COMOSUS (L.) MERR.
}

\author{
${ }^{1,2}$ Pantawat Sampanpanish and ${ }^{3}$ Tippawan Pojanaporn \\ ${ }^{1}$ Environmental Research Institute, Chulalongkorn University, Bangkok, Thailand \\ ${ }^{2}$ Center of Excellence on Hazardous Substance Management, Bangkok, Thailand \\ ${ }^{3}$ Interdisciplinary Program of Environmental Science, \\ Graduate School, Chulalongkorn University, Bangkok, Thailand
}

Received 2014-03-14; Revised 2014-03-14; Accepted 2014-02-18

\begin{abstract}
The effects of chelating agents on Chromium $(\mathrm{Cr})$ and lead $(\mathrm{Pb})$ absorption were studied by planting pineapple, Ananas comosus (L.) Merr. in contaminated soil. All plant samples were grown in a nursery for 30 days and then separated into seven sets: Set (1) had nothing added (Blank); (2) had Pb added as Pb(II) Nitrate $\left(\mathrm{Pb}\left(\mathrm{NO}_{3}\right)_{2}\right)$ at $500 \mathrm{mg} \mathrm{kg}^{-1}$ soil; (3) added $\mathrm{Pb}(\mathrm{II})$ nitrate and EDTA, a chelating agent; (4) contained both $\mathrm{Pb}$ (II) nitrate and EDDS, a second chelating agent; (5) only added $\mathrm{Cr}$ as potassium dichromate $\left(\mathrm{K}_{2} \mathrm{Cr}_{2} \mathrm{O}_{7}\right)$, at $400 \mathrm{mg}$ $\mathrm{kg}^{-1}$ soil; (6) was treated with $\mathrm{Cr}$ (potassium dichromate) plus EDTA; and (7) contained both $\mathrm{Cr}$ (potassium dichromate) and EDDS. The chelating agent concentrations were 2 millimoles per kilogram soil. Soil and plant contamination levels were measured by analyzing the $\mathrm{Cr}, \mathrm{Cr}(\mathrm{VI})$ and total $\mathrm{Pb}$ after growing for $30,60,90$ and 120 days. The analysis divided the plant samples into two parts: Aboveground and underground. Plant growth was also analyzed by dry weight, root length and expression of toxicity through withered leaves and yellow leaf symptoms. The results of this study indicate that after 60 days, the EDTA agent had the highest Pb absorption efficiency, with the plant sample absorbing $288.14 \mathrm{mg} \mathrm{Pb}$ per $\mathrm{kg}$ soil in the aboveground part and $796.66 \mathrm{mg} \mathrm{kg}^{-1}$ soil in the underground part. The EDTA agent had high $\mathrm{Cr}$ absorption efficiency, with the plant sample absorbing $\mathrm{Cr}$ at $545.72 \mathrm{mg} \mathrm{kg}^{-1}$ soil in the aboveground part and $2267.99 \mathrm{mg} \mathrm{kg}^{-1}$ soil in the underground part after 90 days. The EDTA and EDDS agents did not affect pineapple growth and expression of toxicity symptoms were statistically significant $(\mathrm{p} \leq 0.05)$ compared with the control sets.
\end{abstract}

Keywords: EDTA, EDDS, Cr, Pb, Phytoremediation, Ananas Comosus

\section{INTRODUCTION}

Heavy metals affect human daily life because of their long-term environmental stability. The main sources of these hazardous substances are industrial and agricultural activities.Some hevy metals such as Chromium $(\mathrm{Cr})$ and lead $(\mathrm{Pb})$ are toxic to humans at low levels. The presence of heavy metal contamination in water, air and soil can disrupt human and animal life cycles and cause damage to the food chain through bio-accumulation. Soil remediation methods include physical, chemical and biological techniques. For example, one physical technique involves washing contaminated soil to achieve a steady state; a chemical technique uses sedimentation and chemical reduction and biological techniques make use of absorption by microorganism and using plants for containment, degradation or extraction of xenobiotics from water and soil substrates through a process known as phytoremediation (Sampanpanish et al., 2006; Abdu et al., 2011). This biological technique offers an economical and non-invasive alternative for treating polluted soils. Phytoremediation is also recognized as a green technology (Kumar et al., 1995; Huang et al., 1997; Salt et al., 1997; Blaylock et al., 1997; Vassil et al., 1998; Mohd et al., 2013) and removes Corresponding Author: Pantawat Sampanpanish, Environmental Research Institute, Chulalongkorn University, Bangkok, Thailand 
pollutants from contaminated soils by root absorption and translocation to harvestable plant parts. Rajoo et al. (2013).

This study examined enhanced phytoremediation of heavy metals using chelating agents to improve the solubility of heavy metals from soil. Two chelating agents, Ethylene Diaminete Traacetic Acid (EDTA) and Ethylene Diamine Disuccinate (EDDS), were selected for their efficiency as soil amendments. EDTA and EDDS differ significantly in their distinguishing characteristics. EDTA is resistant to biodegradation and has a high environmental persistence. EDTA therefore exhibits a prolonged presence in the soil and presents an increased risk of leaching. On the other hand, EDDS is produced naturally by a number of microorganisms and is readily biodegradable.

The plant species used for phytoremediation in this study was Ananas comosus (L.) Merr. (Pineapple), grown in an agricultural soil contaminated with $\mathrm{Cr}$ and $\mathrm{Pb}$, resulting from disposal of solid hazardous waste from a nearby industrial zone in the eastern part of Thailand. Pineapple is the dominant crop in this area, favored due to its rapid growth and high yield. Therefore, it is pertinent to explore pineapple's ability to absorb and translocate heavy metals as a potential means of bioremediation. The objective of this study was to compare the ability of the two chelating agents, EDTA and EDDS, in increasing uptake of $\mathrm{Cr}$ and $\mathrm{Pb}$.

\section{MATERIALS AND METHODS}

\subsection{Preparation of Soil, Plants and Reagents}

Samples were first collected from uncontaminated soils in eastern of Thailand. Samples were randomly taken from depths of 0-30 centimeters. The samples were dried and analyzed for their general properties and total heavy metal content. This step involved determining aspects such as soil texture, moisture content, $\mathrm{pH}$, the Cation Exchange Capacity (CEC), Conductivity (EC) and Organic Matter (OM), total nitrogen (N), Phosphorus (P) and potassium $(\mathrm{K})$ as well as the presence of naturally occurring heavy metals (e.g., total $\mathrm{Cr}, \mathrm{Cr}(\mathrm{VI})$ and total $\mathrm{Pb}$ ).

Black plastic 8 inch diameter pots containing 5 kilograms of dry soil each were used in the experiment. A total of 84 pots covered with thick transparent plastic bags were prepared. The plants used were Ananas comosus (L.) Merr. Selected for uniform size and weight.

The $\mathrm{Cr}$ and $\mathrm{Pb}$ contaminants used $\left(\mathrm{K}_{2} \mathrm{Cr}_{2} \mathrm{O}_{7}\right.$ and $\left.\mathrm{Pb}\left(\mathrm{NO}_{3}\right)_{2}\right)$ were in the ratio of $400 \mathrm{mg} \mathrm{kg}^{-1}$ soil for $\mathrm{Cr}$ and $500 \mathrm{mg} \mathrm{kg}^{-1}$ of soil for $\mathrm{Pb}$. Each soil sample weighed $5 \mathrm{~kg}$.
The two chelating agents, EDTA and EDDS, were prepared at a concentration of 2 millimoles per $\mathrm{kg}$ soil. $\mathrm{Na}_{2}$ EDTA and $\mathrm{Na}_{3}$ EDDS salt were used to make a solution with a soil concentration ratio of 774.48 and $578.39 \mathrm{mg} \mathrm{kg}^{-1}$ for EDTA and EDDS, respectively.

\subsection{The Experiment}

Experimental plants were thinned to 1 per pot and allowed to grow for approximately 30 days. Soil moisture content was maintained by adding $100 \mathrm{mg}$ of water per pot every day. After selecting plants with healthy root systems, the $\mathrm{Cr}$ and $\mathrm{Pb}$ contaminates were introduced using a solutions of $\mathrm{K}_{2} \mathrm{Cr}_{2} \mathrm{O}_{7}$ and $\mathrm{Pb}\left(\mathrm{NO}_{3}\right)_{2}$ at concentrations of 400 and $500 \mathrm{mg} \mathrm{kg}^{-1}$ of soil, respectively. The pots were separated into seven sets: (1) had 12 pots without any treatments (blank); (2) had 12 pots to which $\mathrm{Pb}$ but no chelating agents was added; (3) had 12 pots to which both $\mathrm{Pb}$ and EDTA were added; (4) had 12 pots to which both $\mathrm{Pb}$ and EDDS were added; (5) had 12 pots to which $\mathrm{Cr}$ but no chelating agents were added; (6) had 12 pots to which both $\mathrm{Cr}$ and EDTA were added; and (7) had 12 pots to which both $\mathrm{Cr}$ and EDDS were added. The experimental design tested these seven sets in three replicates. Addition of 100 milliliters of water every two days in the morning was necessary to keep the soil moist. However, the absorption mechanism might be from the plastic bags that covered the pot when the plants needed more water in the drier part of the day. No fertilizers were used in the experiment.

\subsection{Sampling and Analysis}

Soil and plant samples were taken at intervals of 30 , 60, 90 and 120 days after adding the $\mathrm{Cr}, \mathrm{Pb}$ and chelating agents. Soil and plants were analyzed for total $\mathrm{Cr}, \mathrm{Cr}(\mathrm{VI})$ and total $\mathrm{Pb}$. The soil samples were dried at room temperature and separated into two parts. One part was ground and sieved by a No.2 sieve apparatus, kept in a storage bag and analyzed for background. The other part was dried in an oven at $105^{\circ} \mathrm{C}$ for $48 \mathrm{~h}$, ground and sieved by a No.2 sieve apparatus, then analyzed for $\mathrm{Cr}$ and $\mathrm{Pb}$ concentrations. The plants were washed 2-3 times with tap water, using distilled water for the final rinse. Also, the plants were separated into two classes: Aboveground parts (stems and leaves); and underground parts (stem and roots). The fresh plants were weighed then oven-dried at $105^{\circ} \mathrm{C}$ for $48 \mathrm{~h}$ until a stable dry weight was reached and recorded. The dried plant samples were ground and sieved using a No.2 sieve apparatus and analyzed for total $\mathrm{Cr}, \mathrm{Cr}(\mathrm{VI})$ and total $\mathrm{Pb}$, in each part of the plant. Total $\mathrm{Cr}$ and $\mathrm{Pb}$ in the soil and 
plant samples were determined using the USEPA 3052 method,acid digestion and by microwave digestion with the total amount calculated by Atomic Absorption Spectrometer; AAS. The Cr(VI) concentration in soil and plant was analyzed by using USEPA 3060 method and the total amount calculated by UV spectrophotometer.

\subsection{Statistical Analysis}

Descriptive statistics were performed using the Statistic Package for Social Science; SPSS. The variance absorption data and the accumulation of $\mathrm{Cr}$ and $\mathrm{Pb}$ within plants were analyzed using ANOVA and the results were compared to different data by Duncan's New Multiple Range Test; DMRT.

\section{RESULTS}

\subsection{The Properties of Soil Samples}

The uncontaminated soil used in the experiment was a sandy clay loam with sand: Silt: Clay ratio of 63.80: 5.40: 30.80. The other soil properties are shown in Table $\mathbf{1}$ and demonstrate the acidity of the soil.

\subsection{Accumulation of Chromium and Lead in Soil Samples}

The accumulation of $\mathrm{Cr}$ and $\mathrm{Pb}$ in the soil is shown in Table 2. Soil samples at 30, 60, 90 and 120 days showed that the total amounts of $\mathrm{Cr}$ and $\mathrm{Pb}$ in the soil decreased over time. The soil samples had low levels of organic matter and low $\mathrm{pH}$, which increase solubility of $\mathrm{Cr}$ and $\mathrm{Pb}$ compounds, enhancing root uptake. High plant growth rate was associated with enhanced reduction in total soil $\mathrm{Cr}$ and $\mathrm{Pb}$. The results for experimental sets 5, 6 and 7 showed that the total amount of $\mathrm{Cr}(\mathrm{VI})$ in the soil decreased as time increased from 30 to 120 days. By contrast, the total amount of $\mathrm{Cr}$ (III) increased as time increased from 30 to 120 days. $\mathrm{Cr}(\mathrm{VI})$ is reduced in the soil to $\mathrm{Cr}$ (III) (Grohse et al., 1988).

\subsection{Effect of Chelating Agent on $\mathrm{Cr}$ and $\mathrm{Pb}$ Uptakein Plants}

The study of $\mathrm{Cr}$ and $\mathrm{Pb}$ accumulation in plants was focused on two parts: Aboveground (stem and leaf) and underground (stem and roots). The results are shown in Fig. 1 and 2.

\subsubsection{Cr Accumulation in Whole Part of Plants}

The total amount of $\mathrm{Cr}$ absorbed is shown in Fig. 1a and $\mathbf{b}$ which depict absorption by chelating agents of $\mathrm{Cr}$ from soil into the plant. The most significant finding was the amount of $\mathrm{Cr}$ absorbed into whole part of plant. The Cr solution concentrations in soil of 400 $\mathrm{mg} \mathrm{kg}^{-1}$ soil were applied to one kilogram of soil at various times: 30, 60, 90 and 120 days. The result was that the underground parts (stem and roots) accumulated more $\mathrm{Cr}$ solution than the aboveground parts (stem and leaf). In particular, pineapple plants from experimental set 6 absorbed the most $\mathrm{Cr}$ after 90 days. The aboveground parts absorbed 545.72 milligrams per kilogram plant and underground parts absorbed 2,267.99 $\mathrm{mg} \mathrm{kg}^{-1}$ of plant. A study by (Lombi et al., 2001) found that EDTA was highly efficient in transferring $\mathrm{Cr}$ from soil to root, but limited in its ability to transfer $\mathrm{Cr}$ from root to stem. A study by (Lemen et al., 2002) found that certain plants may limit Cr transfer from stem to leaf. Nevertheless, absorption of $\mathrm{Cr}(\mathrm{VI})$ was highest at 30 days in both parts of pineapple in this study, with $224.12 \mathrm{mg} \mathrm{kg}^{-1}$ plant in aboveground parts and $826.74 \mathrm{mg} \mathrm{kg}^{-1}$ plant for underground parts. The aboveground parts from experimental set 7 absorbed the TCr after 90 days, but the underground parts absorbed the TCr only after 120 days: $513.68 \mathrm{mg} \mathrm{kg}^{-1}$ plant and 2,124.48 $\mathrm{mg} \mathrm{kg}^{-1}$, respectively. However, the absorption of $\mathrm{Cr}(\mathrm{VI})$ by aboveground parts from experimental set 7 was highest at 60 days and absorption by underground parts was highest at 30 days: $198.88 \mathrm{mg} \mathrm{kg}^{-1}$ plant and $784.61 \mathrm{mg}$ $\mathrm{kg}^{-1}$ plant, respectively. The experimental time periods of 30 and 60 days showed statistically significant relationships between experimental set 6 (which added both $\mathrm{Cr}$ and EDTA) and both experimental set 5 (added $\mathrm{Cr}$ but did not add chelating agents) and experimental set 7 (added both $\mathrm{Cr}$ and EDDS) at $\mathrm{p} \leq 0.05$.

Table 1. Physical and chemical properties of the soil used in the study

\begin{tabular}{|c|c|}
\hline Soil properties & Soil values \\
\hline Sand $(\%)$ & 63.80 \\
\hline Silt $\quad(\%)$ & 5.40 \\
\hline Clay $(\%)$ & 30.80 \\
\hline Soil texture & Sandy clay loam \\
\hline pH (1:1 soil: Water) & 4.4 \\
\hline Cation exchange capacity $\left(\mathrm{c} \mathrm{mol}_{(\mathrm{c})} \mathrm{kg}^{-1}\right)$ & 3.5 \\
\hline Electrical conductivity $\left(\mathrm{dSm}^{-1}\right)$ & 0.06 \\
\hline Organic matter $(\%)$ & 0.64 \\
\hline Total N (\%) & 0.03 \\
\hline Available $\mathrm{P}\left(\mathrm{mg} \mathrm{kg}^{-1}\right)$ & 6.0 \\
\hline Exchangeable $\mathrm{K}\left(\mathrm{mg} \mathrm{kg}^{-1}\right)$ & 48.0 \\
\hline $\mathrm{TCr}\left(\mathrm{mg} \mathrm{kg}^{-1}\right)$ & $\mathrm{ND}^{*}$ \\
\hline $\mathrm{TPb}\left(\mathrm{mg} \mathrm{kg}^{-1}\right)$ & $\mathrm{ND}^{*}$ \\
\hline
\end{tabular}

Note: $* \mathrm{ND}=$ Not Detectable $(<0.5 \mathrm{ppm})$ 
Table 2. The accumulation of $\mathrm{Cr}$ and $\mathrm{Pb}$ in the soil samples

\begin{tabular}{|c|c|c|c|c|}
\hline \multirow[b]{2}{*}{ Experimental sets } & \multicolumn{4}{|l|}{ Days } \\
\hline & 30 & 60 & 90 & 120 \\
\hline Control $\mathrm{TPb}$ & $476.71 \pm 2.71$ & $469.64 \pm 1.52$ & $459.07 \pm 3.77$ & $451.17 \pm 6.63$ \\
\hline Control TCr & $364.57 \pm 5.24$ & $357.85 \pm 1.31$ & $354.19 \pm 4.13$ & $346.34 \pm 2.33$ \\
\hline Control $\mathrm{Cr}(\mathrm{VI})$ & $249.06 \pm 6.06$ & $209.68 \pm 16.24$ & $156.64 \pm 1.48$ & $114.22 \pm 4.17$ \\
\hline Control Cr(III) & $115.51 \pm 7.25$ & $148.60 \pm 8.20$ & $197.56 \pm 4.78$ & $232.13 \pm 5.90$ \\
\hline Cr EDTA TCr & $346.44 \pm 1.81$ & $337.33 \pm 1.99$ & $334.63 \pm 0.68$ & $336.42 \pm 0.67$ \\
\hline Cr EDDS TCr & $354.52 \pm 2.17$ & $346.66 \pm 4.14$ & $345.72 \pm 1.84$ & $344.48 \pm 1.57$ \\
\hline Cr EDTA Cr(VI) & $207.62 \pm 17.50$ & $180.14 \pm 8.31$ & $142.35 \pm 2.43$ & $93.34 \pm 2.61$ \\
\hline Cr EDDS Cr(VI) & $216.72 \pm 1.80$ & $188.21 \pm 10.90$ & $158.51 \pm 3.64$ & $107.04 \pm 3.47$ \\
\hline Cr EDTA Cr(III) & $138.82 \pm 16.61$ & $157.19 \pm 4.82$ & $191.68 \pm 5.42$ & $243.10 \pm 2.85$ \\
\hline Cr EDDS Cr(III) & $137.81 \pm 1.60$ & $158.45 \pm 5.06$ & $187.21 \pm 4.69$ & $237.44 \pm 5.00$ \\
\hline $\mathrm{Pb}$ EDTA & $460.93 \pm 3.23$ & $448.78 \pm 5.19$ & $447.13 \pm 1.64$ & $444.15 \pm 2.82$ \\
\hline $\mathrm{Pb}$ EDDS & $466.30 \pm 2.22$ & $454.50 \pm 4.72$ & $451.02 \pm 2.01$ & $448.31 \pm 2.47$ \\
\hline
\end{tabular}

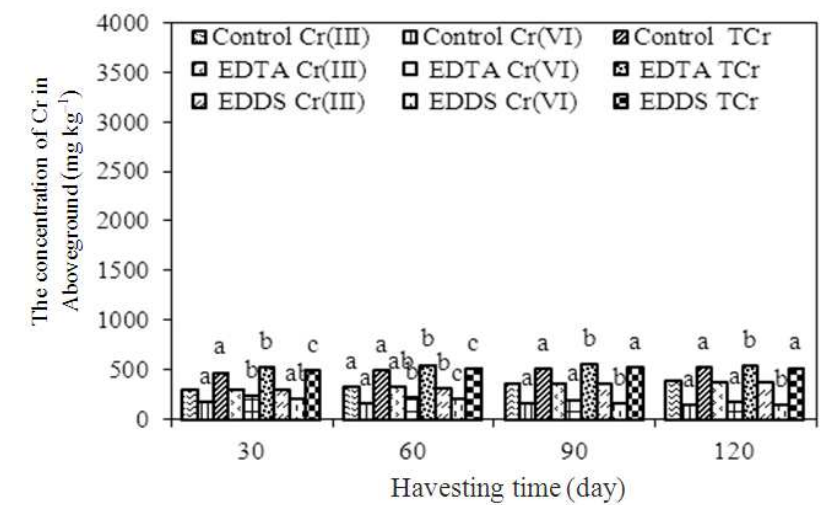

(a)

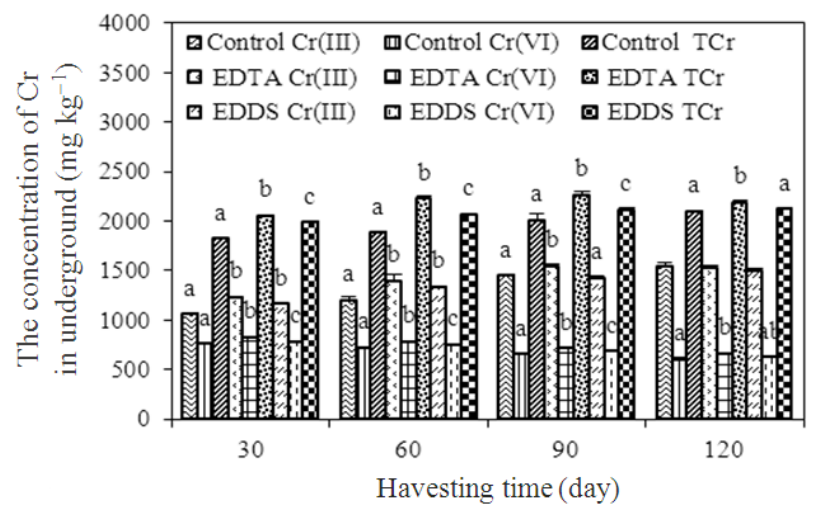

(b)

Fig. 1. $\mathrm{TCr}, \mathrm{Cr}(\mathrm{III})$ and $\mathrm{Cr}(\mathrm{VI})$ in plants (a) Aboveground part and (b) Underground part

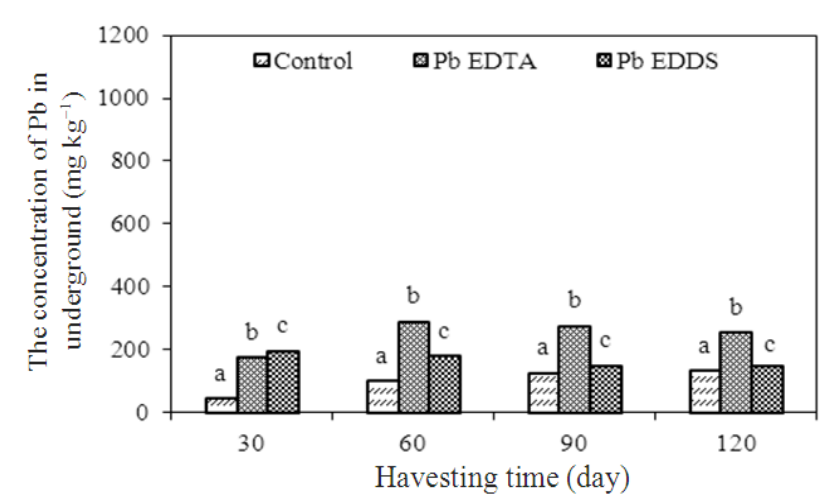

(a)

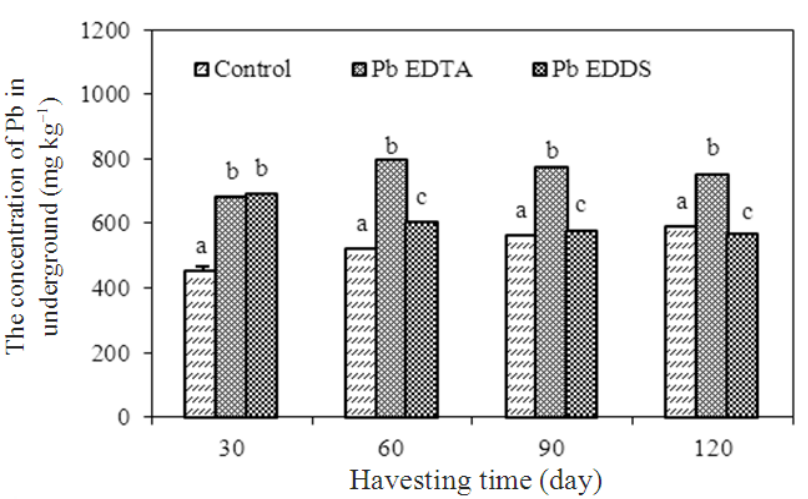

(b)

Fig. 2. The TPb in plant (a) Aboveground part and (b) Underground part

On the other hand, the $\mathrm{Cr}(\mathrm{VI})$ absorption mechanism of aboveground parts and underground parts decreased with increasing time from 30 days to 120 days in experimental set 5 (which added $\mathrm{Cr}$ but did not add chelating agents), experimental set 6 (which added both $\mathrm{Cr}$ and EDTA) and experimental set 7 (which added both $\mathrm{Cr}$ 
and EDDS). That the reduction reaction is a significant plant mechanism that changes $\mathrm{Cr}(\mathrm{VI})$ to $\mathrm{Cr}(\mathrm{III})$ is noted in Shanker et al., 2005; Grohse et al., 1988).

\subsubsection{Pb Accumulation in Whole Part of Plants}

The total amount of $\mathrm{Pb}$ absorbed in plant is shown in Fig. 2a and b. These data describe the absorption effect of chelating agents on soil $\mathrm{Pb}$, as well as the effect of the pineapple plant parts. The most significant finding is that the amount of $\mathrm{Pb}$ increased in all parts of the pineapple plant. Soil $\mathrm{Pb}$ concentrations of 500 milligrams were applied to one kilogram of soil at 30, 60, 90 and 120 days. Analysis indicated that the aboveground parts (stem and leaf) accumulated less $\mathrm{Pb}$ than the underground parts (stem and roots). The results showed that the pineapple from experimental set $4(\mathrm{~Pb}+\mathrm{EDDS})$ had the highest ability to absorb $\mathrm{Pb}$ after 30 days when the aboveground parts held $195.12 \mathrm{mg} \mathrm{kg}^{-1}$ plant, while underground parts held $691.44 \mathrm{mg} \mathrm{kg}^{-1}$ plant. On the other hand, experimental set $3(\mathrm{~Pb}+\mathrm{EDTA})$ had the highest ability to absorb $\mathrm{Pb}$ after 60 days, with aboveground parts holding $288.14 \mathrm{mg} \mathrm{kg}^{-1}$ plant and underground parts holding $796.66 \mathrm{mg} \mathrm{kg}$ plant, respectively. The experimental time periods of 60, 90 and 120 days showed statistically significant relationships between experimental set $3(\mathrm{~Pb}+\mathrm{EDTA})$ and both experimental set 2 ( $\mathrm{Pb}$ only-no chelating agents added $)$ andexperimental set $4(\mathrm{~Pb}+\mathrm{EDDS})$ at $\mathrm{p} \leq 0.05$. Therefore the $\mathrm{Pb}$ solution could be transferred more easily under acidic soil conditions and soil $\mathrm{Pb}$ was more available for root absorbtion (Al-Taisan, 2009). Findings from many research studies such as (Huang et al., 1997) who worked with pea (Pisumsativum L.cv. Sparkle) are consistent with the findings of the current study.

EDTA increased $\mathrm{Pb}$ absorption potential in soil and the chelating agent affected $\mathrm{Pb}$ accumulation in the aboveground plant parts. Significantly, this research confirmed the different characteristics of EDDS and EDTA as chelating agents. EDTA was found to act more slowly than EDDS and had ahigher absorption efficiency. The comparative analysis of the efficiency of EDTA and EDDS showed that heavy metal absorption in the soil increased at the same concentration and the EDTA agent had higher absorption efficiency than EDDS (Luo et al., 2005). Inanother study, BrassiarapaL. was used in order to study its absorption efficiency for $\mathrm{Pb}, \mathrm{Zn}$ and $\mathrm{Cd}$. In that experiment the effects of adding ETDA with EDDS were compared. This experiment also found higher efficiencies for EDTA, compared with EDDS (Grcman et al., 2003).

\subsection{Efficiency of Chelating Agents on Absorptionof $\mathrm{Cr}$ and $\mathrm{Pb}$ by Plant}

Data on the efficiency of two chelating agents, EDTA and EDDS, are presented in Fig. 3a and b. The EDTA agent had $\mathrm{Pb}$ absorption efficiencies of $0.31,0.46,0.61$ and $0.69 \%$ when time increased from 30 to 120 days, respectively. Moreover, the EDTA agent had higher $\mathrm{Pb}$ absorption efficiency than EDDS at 60, 90 and 120 days when statistically significant relationships were considered. On the other hand, the EDTA and EDDS agent had similar $\mathrm{Cr}$ absorption efficiencies at 30 and 60 days, but EDTA had higher efficiency after 90 days where EDTA was $5.3 \%$ and EDDS was $4.5 \%$. Many other published research studies support these results. For example, a study of $\mathrm{Cu}, \mathrm{Pb}, \mathrm{Zn}$ and $\mathrm{Cd}$ absorption efficiency in Zea mays L. and Chrysanthemum coronariumshowed that the EDTA agent had higher $\mathrm{Pb}$ absorption efficiency than the EDDS agent (Luo et al., 2006). The EDTA agent had higher $\mathrm{Cr}$ absorption efficiency than oxalic acid (Hsiao et al., 2007) and the EDTA agent had high heavy metal absorption efficiency from soil, but had limited ability to transfer this solution from root to leaf (Madrid et al., 2003).

\subsection{Effect of Chelating Agent on Growth of Plants}

The study of pineapple growth considered plant dry weight and observed expressions of toxicity including withered or yellow leaves and truncated roots. The results are shown in Fig. 4.

Plant dry weight of aboveground and underground parts in samples with only $\mathrm{Cr}, \mathrm{Cr}+$ EDTA and $\mathrm{Cr}+\mathrm{EDDS}$ as shown in Fig. 4a and b, decreased with time from 60 to 120 days. Plant samples without added $\mathrm{Cr}$ or with $\mathrm{Cr}+$ chelating agent showed statistically significant relationships. These results indicate limited plant growth when $\mathrm{Cr}$ was absorbed, as seen in other studies. For example, dry weight of cabbage samples decreased from 88.4 to 28.4 grams when $\mathrm{Cr}$ was added at a level of $10 \mathrm{mg}$ $\mathrm{kg}^{-1}$ soil (Hara and Sonoda, 1979). Table 3 shows root length data from all seven experimental sets: Blank, $\mathrm{Cr}$ or $\mathrm{Pb}$ only, $\mathrm{Cr}$ or $\mathrm{Pb}+\mathrm{EDTA}$ and $\mathrm{Cr}$ or $\mathrm{Pb}+\mathrm{EDDS}$. Root length of the untreated control sample was longer than all other treatments, consistent with other studies of the effect of $\mathrm{Cr}$ on root elongation (Panda and Patra, 2000). Root length actually decreased when 1 micromole of $\mathrm{Cr}$ was added. Moreover, Caesalpiniapulcherrimaroot and dry weight were limited by $\mathrm{Cr}$ at a concentration of $100 \mathrm{mg} \mathrm{kg}^{-1}$ (Prasad et al., 2001). 
P. Sampanpanish and T. Pojanaporn / American Journal of Agricultural and Biological Sciences 9 (3): 361-368, 2014

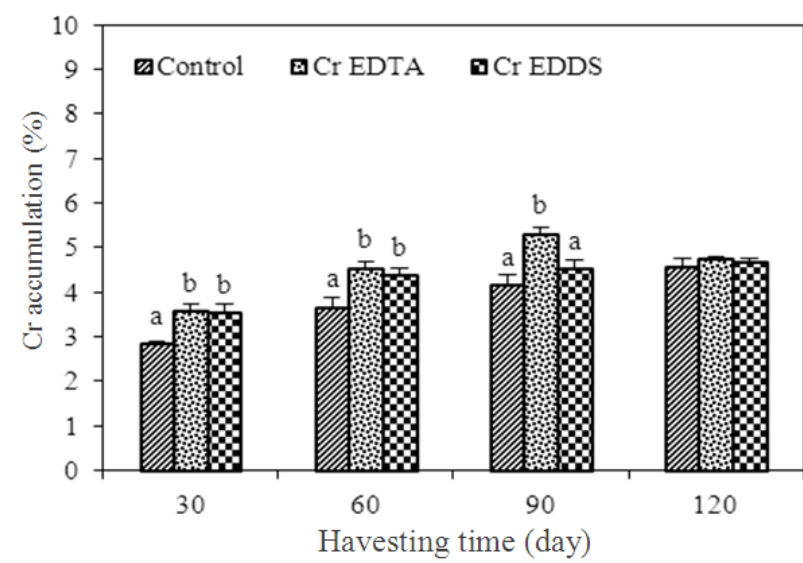

(a)

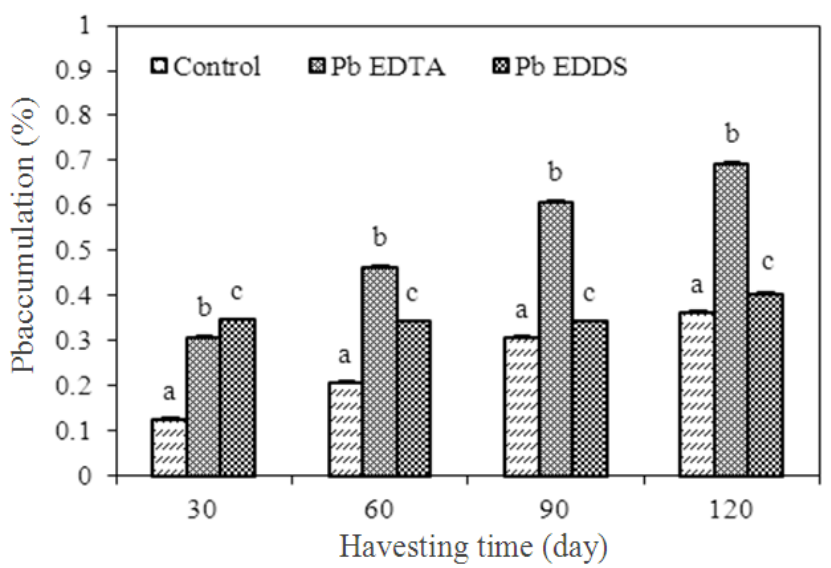

(b)

Fig. 3. Efficiency of the chelating agent on percent absorption (a) $\mathrm{Cr}$ and (b) $\mathrm{Pb}$

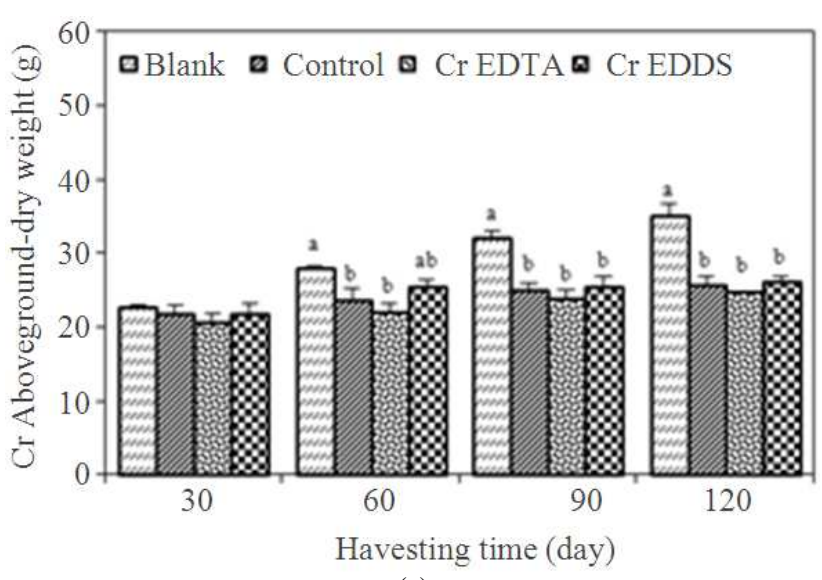

(a)

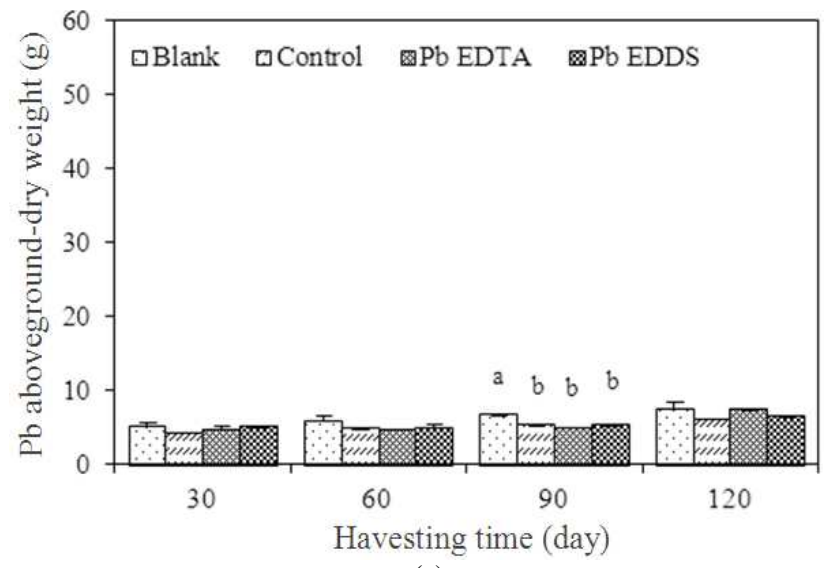

(a)

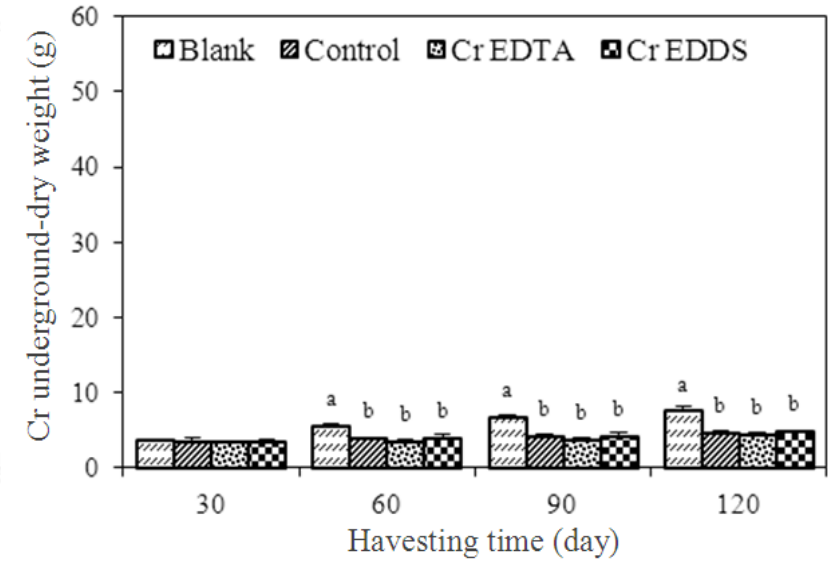

(b)

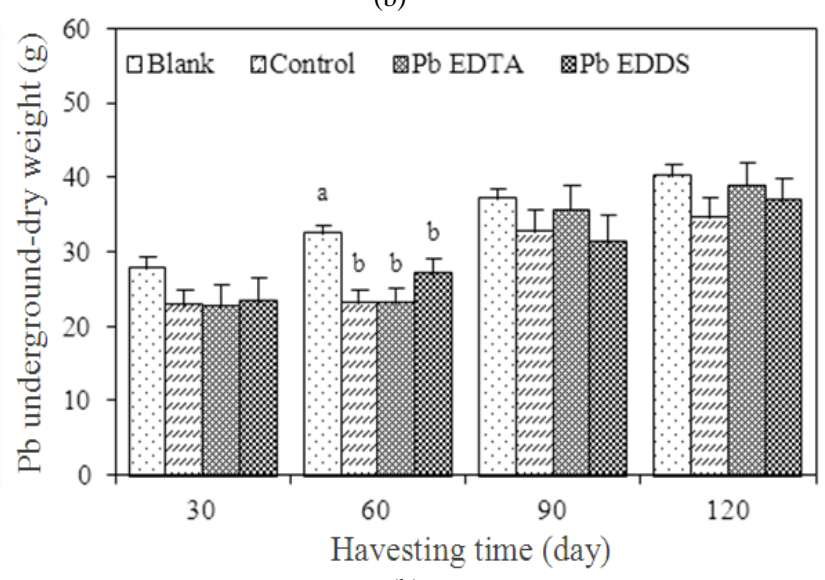

(b)

Fig. 4. Plant dry weight of samples with added $\mathrm{Cr}$ or $\mathrm{Pb}$ (a) and (c) aboveground part and (b) and (d) underground part 
P. Sampanpanish and T. Pojanaporn / American Journal of Agricultural and Biological Sciences 9 (3): 361-368, 2014

Table 3. Root length data from all seven experimental sets: $\mathrm{Blk}, \mathrm{Cr}$ or $\mathrm{Pb}$ only, $\mathrm{Cr}$ or $\mathrm{Pb}+\mathrm{EDTA}, \mathrm{Cr}$ or $\mathrm{Pb}+\mathrm{EDDS}$

\begin{tabular}{|c|c|c|c|c|}
\hline Time (day) & Blank & Control & EDTA & EDDS \\
\hline \multicolumn{5}{|c|}{$\overline{\text { Cr/root length }(\mathrm{cm})}$} \\
\hline 30 & $11.57 \pm 0.55$ & $8.13 \pm 0.79 b$ & $7.43 \pm 0.44 b$ & $8.10 \pm 0.40 \mathrm{~b}$ \\
\hline 60 & $18.13 \pm 1.09 \mathrm{a}$ & $10.43 \pm 0.71 b c$ & $9.10 \pm 0.81 \mathrm{c}$ & $10.43 \pm 0.69 b c$ \\
\hline 90 & $22.73 \pm 0.78 \mathrm{ab}$ & $12.13 \pm 1.08 \mathrm{c}$ & $12.80 \pm 1.64 \mathrm{c}$ & $13.13 \pm 1.26 \mathrm{c}$ \\
\hline 120 & $36.07 \pm 1.30 \mathrm{a}$ & $14.90 \pm 1.37 \mathrm{c}$ & $14.10 \pm 1.19 \mathrm{c}$ & $13.90 \pm 1.25 \mathrm{c}$ \\
\hline \multicolumn{5}{|c|}{$\mathrm{Pb} /$ root length $(\mathrm{cm})$} \\
\hline 30 & $11.57 \pm 0.55 \mathrm{a}$ & $9.90 \pm 1.28 \mathrm{ab}$ & $11.66 \pm 1.11 \mathrm{a}$ & $9.87 \pm 0.61 \mathrm{ab}$ \\
\hline 60 & $18.13 \pm 1.09 \mathrm{a}$ & $10.13 \pm 0.92 b c$ & $13.40 \pm 1.67 \mathrm{~b}$ & $18.90 \pm 1.14 \mathrm{a}$ \\
\hline 90 & $22.73 \pm 0.78 \mathrm{ab}$ & $20.40 \pm 0.51 b$ & $25.73 \pm 2.83 \mathrm{a}$ & $22.73 \pm 0.64 \mathrm{ab}$ \\
\hline 120 & $36.07 \pm 1.30 \mathrm{a}$ & $27.73 \pm 2.03 b$ & $33.23 \pm 1.91 \mathrm{ab}$ & $31.6 \pm 3.35 \mathrm{ab}$ \\
\hline
\end{tabular}

Moreover, dry weight of aboveground and underground parts in samples that had only $\mathrm{Pb}$, $\mathrm{Pb}+\mathrm{EDTA}$ and $\mathrm{Pb}+\mathrm{EDDS}$ (shown in Fig. 4c and d) was closer over time to samples that did not have $\mathrm{Pb}$ or both $\mathrm{Pb}$ and chelating agents. These were statistically significant relationships. From the Table 3 shows that the root length of the untreated control sample were similar to the samples with only $\mathrm{Pb}$ and $\mathrm{Pb}+$ chelating agents. Again, these were statistically significant relationships. The chelating agents did not affect dry weight of the plants and these results agree with findings from other research. For example, EDDS increased efficiency of heavy metal absorption but did not affect plant growth when compared to blank samples (Punshon, 1996). EDTA did not affect cabbage dry weight at a concentration of 3 millimoles per kilogram soil (Wu et al., 2004). EDTA and EDDS did not affect Helianthus annuus dry weight or growth at a concentration of 1.6 millimole per kilogram soil (Meer et al., 2005).

\section{CONCLUSION}

The conclusion from this study is that the EDTA agent promotes higher $\mathrm{Cr}$ and $\mathrm{Pb}$ uptake from soil than the EDDS agent. Moreover, two chelating agentsdid cause negative effects on growth rate of pineapple. In phytotoxicity studies of $\mathrm{Cr}$ and $\mathrm{Pb}$ no negative effects were observed on the pineapplein all of the experiment. Thus, the results of our experiment can be applied to help manage this problem. EDTA is suitable and should be promoted for use in $\mathrm{Cr}$ and $\mathrm{Pb}$ removal from soil using pineapple.

\section{ACKNOWLEDGEMENT}

We thank the Interdisciplinary Program of Environmental Science, Graduate School, Chulalongkorn University, the Environmental Research Institute (ERIC) and the Center of Excellence on Hazardous Substance Management
(HSM), Chulalongkorn University for all the support, practical information, helpful instruments and excellent suggestions. Moreover, we are pleased to express our thanks to every person who gave us so much help.

\section{REFERENCES}

Abdu, A., N. Aderis, H. Abdul-Hamid, N.M. Majid and S. Jusop et al., 2011. Using Orthosiphon stamineus B. for Phytoremediation of heavy metals in soils amended with sewage sludge. Am. J. Applied Sci., 8: 323-331. DOI: 10.3844/ajassp.2011.323.331

Al-Taisan, W.A., 2009. Suitability of using Phragmites australis and Tamarix aphylla as vegetation filters in industrial areas. Am. J. Environ. Sci., 5: 740-747. DOI: 10.3844/ajessp.2009.740.747

Blaylock, M.J., D.E. Salt, S. Dushenkow, O. Zakharova and C. Gussman et al., 1997. Enhanced accumulation of $\mathrm{Pb}$ in Indian mustard by soilapplied chelating agents. Environ. Sci. Technol., 31: 860-865. DOI: 10.1021/es960552a

Grcman, H., D. Vodnik, S. Velikonja-Bolta and D. Lestan, 2003. Ethylenediaminedissuccinate as a new chelate for environmentally safe enhanced lead phytoextraction. J. Environ. Q., 32: 500-506. DOI: 10.2134/jeq2003.5000

Grohse, P.M., W.F. Gutknecht, L. Hodson and B.M. Wilson, 1988. The fate of hexavalent chromium in the atmosphere. California Air Resources Board, CARB Contract No. A6-096-32, Triangle Institute.

Hara, T. and Y. Sonoda, 1979. Comparison of the toxicity of heavy metals to cabbage growth. Plant Soil, 51: 127-33. DOI: 10.1007/BF02205932

Huang, J.W., J. Chen, W.B. Berti and S.D. Cunningham, 1997. Phytoremediation of lead-contaminated soils: Role of synthetic chelates in lead phytoextraction. Environ. Sci. Technol., 31: 800-805. DOI: $10.1021 /$ es 9604828 
Hsiao, K.H., P.H. Kao and Z.Y. Hseu, 2007. Effects of chelators on chromium and nickel uptake by Brassica juncea on serpentine-mine tailings for phytoextraction. J. Hazard. Mat., 148: 366-376. DOI: 10.1016/j.jhazmat.2007.02.049

Kumar, P.B.A.N., V. Dushenkov, H. Motto and I. Raskin, 1995. Phytoextraction: The use of plants to remove heavy metals from soils. Environ. Sci. Technol., 29: 1232-1238. DOI: 10.1021/es00005a014

Lemen, J.K., B.G. Hammond, S.G. Riordan, C. Jiang and M. Nemeth et al., 2002. Toxicology summary report: Summary of study CV-2000-260: 13-week.

Lombi, E., F.J. Zhao, S.J. Dunham and S.P. McGrath, 2001. Phytoremediation ofheavy metal Phytoremediation of heavy metal-contaminated soils: Natural hyperaccumulation versus chemically enhanced phytoextraction. J. Environ. Q., 30: 1919-1926. PMID: 11789997

Luo, C., Z. Shen and X. Li, 2005. Enhanced phytoextraction of $\mathrm{Cu}, \mathrm{Pb}, \mathrm{Zn}$ and $\mathrm{Cd}$ with EDTA and EDDS. Chemosphere., 59: 1-11. DOI: 10.1016/j.chemosphere.2004.09.100

Luo, C.L., Z.G. Shen, X.D. Li and A.J.M. Baker, 2006. Enhanced phytoextraction of $\mathrm{Pb}$ and other metals from artificially contaminated soils through the combined application of EDTA and EDDS. Chemosphere, 63: 1773-1784. DOI: 10.1016/j.chemosphere.2005.09.050

Madrid, F., M.S. Liphadzi and M.B. Kirkham, 2003. Heavy metal displacement in chelate-irrigated soil during phytoremediation. J. Hydrol., 272: 107-119. DOI: 10.1016/S0022-1694(02)00258-5

Meer, E., A. Ruttens, M.J. Hopgood, D. Samson and F.M.G. Tack et al., 2005. Comparison of EDTA and EDDS as potential soil amendments for enhanced phytoextraction of heavy metals. Chemosphere, 58: 1011-1022. DOI: 10.1016/j.chemosphere.2004.09.047

Mohd, S.N., N.M. Majid, N.A.M. Shazili and A. Abdu, 2013. Growth performance, biomass and phytoextraction efficiency of Acacia mangium and Melaleuca cajuputi in remediating heavy metal contaminated soil. Am. J. Environ. Sci., 6: 310-316. DOI: 10.3844/ajessp.2013.310.316
Panda, S.K. and H.K. Patra, 2000. Nitrate and ammonium ions effect on the chromium toxicity in developing wheat seedlings. Proc. Nat. Acad Sci. Ind. Biol. Sci., 70: 75-80.

Prasad, M.N.V., M. Greger and T. Landberg, 2001. Acacia nilotica $\mathrm{L}$. bark removes toxic elements from solution: Corroboration from toxicity bioassay using Salix viminalis L. in hydroponic system. Int. J. Phytoremed., 3: 289-300. DOI: $10.1080 / 15226510108500060$

Punshon, T., 1996. Heavy metal resistance in Salix. MSc. Thesis, Liverpool John Moores University.

Rajoo, K.S., A. Abdu, D.K. Singh, H. Abdul-Hamid and S. Jusop et al., 2013. Heavy metal uptake and translocation by Dipterocarpus verrucosus from sewage sludge contaminated soil. Am. J. Environ. Sci., 9: 259-268. DOI: 10.3844/ajessp.2013.259.268

Sampanpanish, P., W. Pongsapich, S. Khaodhiar and E. Khan, 2006. Chromium removal from soil by phytoremediation with weed plant species in Thailand. Water, Air, Soil Focus. Springer Netherland, 6: 191-206. DOI: 10.107/s11267-0059006-1

Salt, D.E., I.J. Pickering, R.C. Prince, D. Gleba and Dushenkov et al., 1997. Metal accumulation by aquacultured seedlings of Indian mustard. Environ. Sci. Technol., 31: 1636-1644. DOI: 10.1021/es960802n

Shanker, A.K., C. Cerv, H. Loza-Tavera and S. Avudainayagam, 2005. Chromium toxicity in plants. Environ. Int., 31: 739-753. DOI: 10.1016/j.envint.2005.02.003

Vassil, A.D., Y. Kapulnik, I. Raskin and D.E. Salt, 1998. The role of EDTA in lead transport and accumulation by India mustard. Plant Physiol., 117: 447-453. DOI: 10.1104/pp.117.2.447

Wu, L.H., Y.M. Luo, X.R. Xing and P. Christie, 2004. EDTA-enhanced phytoremediation of heavy metal contaminated soil with Indianmustard and associated potential leaching risk. Agri. Ecosyst. Environ., 102: 307-318. DOI: 10.1016/j.agee.2003.09.002 